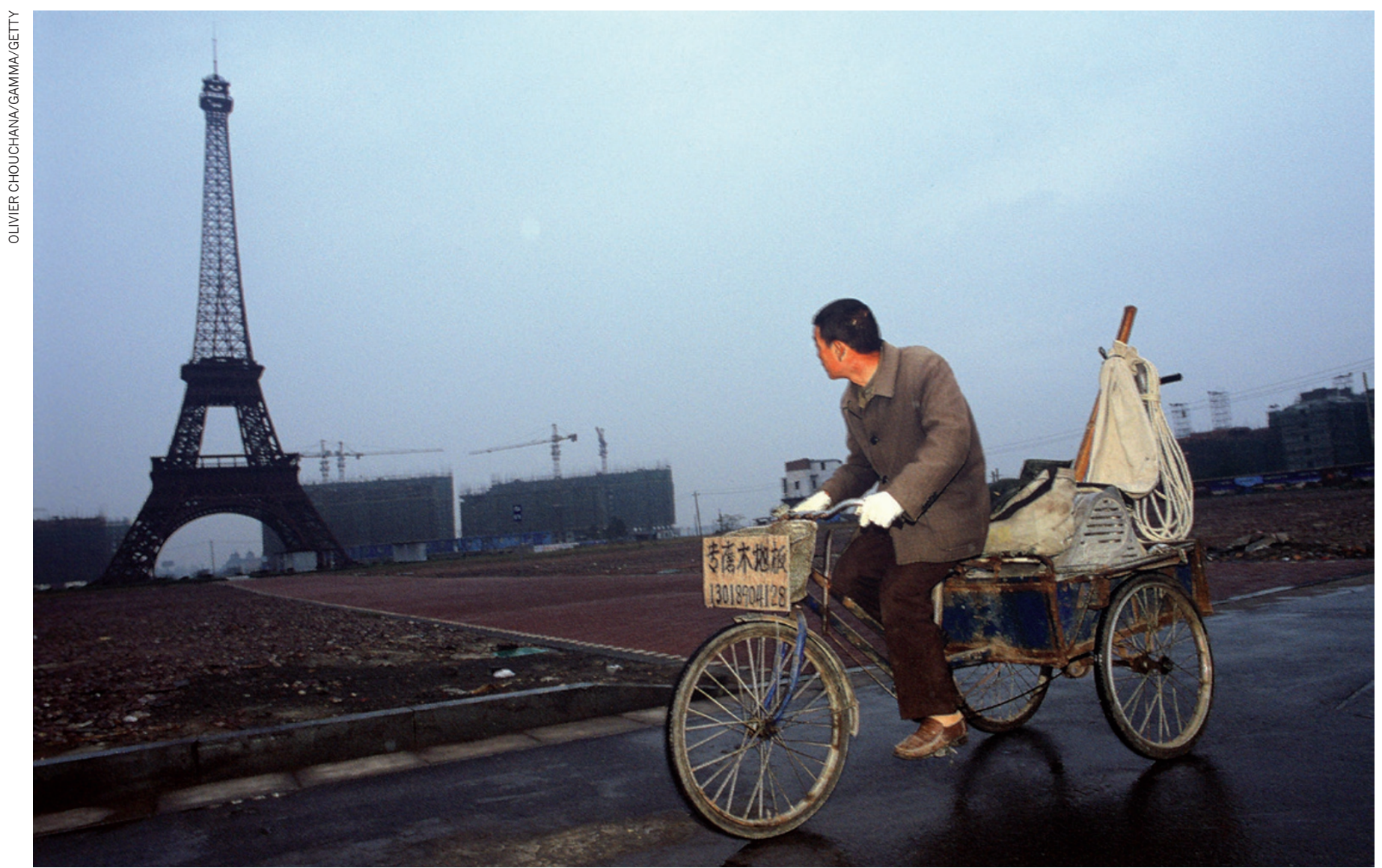

The replica Eiffel Tower in the suburb of Tianducheng in Shanghai, China.

URBAN PLANNING

\title{
Monumental knock-offs
}

\section{Mike Davis on a chronicle of four 'instant' cities modernized by mimicking the West.}

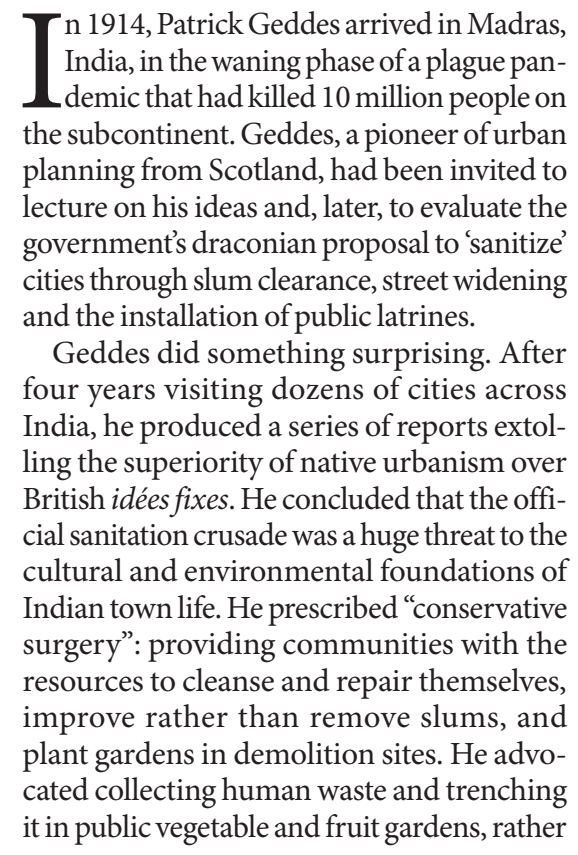

than dumping it into streams or latrines.

His ideas achieved small-scale successes in Lucknow, Baroda and Indore. The larger urbanreform movement in India collapsed after the First World War, in part because of the immense cost of building New Delhi on an imperial scale.

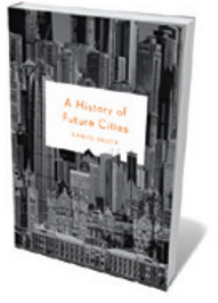

A History of Future Cities

DANIEL BROOK

W. W. Norton: 2013. 480 pp. $\$ 27.95$
Geddes was not an anti-modernist; indeed, he was an enthusiast for concrete and electricity. But he rejected the hubris of British engineers who, ignorant of local 'webs of life, proposed for India the same drastic palliatives that had been applied to industrial British cities such as Liverpool and Glasgow. Geddes' work poses an enduring question: why do politicians, bankers and developers continue to ignore the local genius of nonWestern architectures and urban life, and promote generic urban modernity?

This is a question that Daniel Brook should have tackled in A History of Future Cities, his fascinating parallel social histories of St Petersburg, Shanghai, Mumbai and Dubai as deliberately constructed facsimiles of the distant modernities of Amsterdam, London and Las Vegas. These 'instant' cities are light years away from the tinkering, incremental urbanism advocated by Geddes, which thrives today in self-built slums. The global middle classes, especially in Asia, seem to prefer theme-park cities with replicas of the Eiffel Tower (in Tianducheng, a suburb of Shanghai) and gated subdivisions copied from The Real Housewives of Orange County (in Ju Jun, for example, near Beijing).

Brook is undismayed by the popularity of simulated landscapes and monumental knock-offs. Unlike Geddes, he does not see urban conservation as the precondition 
$>$ of modernization. Authentic modernity, Brook argues, is usually the conquest and transformation of a copy of somewhere else. From a historical perspective, "impersonation is often just a first step, not a final destination in a place's development". To illustrate this thesis, he traces the "idea of Dubai" back to the building of St Petersburg as a copy of Amsterdam, and later through Shanghai and Bombay (now Mumbai) as artificial iterations of English cities.

My experience of reading this book, however, would have been much happier without the introduction. In it, Brook, in my view, depicts sophisticated Chinese and Indian civilizations almost as if they were stunned hunter-gathers seeing iron tools for the first time: "to their Chinese and Indian inhabitants these strange new buildings and the cosmopolitan cities themselves were, by turns, confusing, threatening, and inspiring." Likewise, Brook's assertion that "the idea of Dubai ... is the idea of our time: the Asian Century, which is also the Urban Century" would make a good slogan for the side of an Emirates passenger jet; but I dread to think that a debt-ridden absolute monarchy exploiting foreign labour might be the shape of things to come.

Once past the clichés, the studies of St Petersburg, Shanghai and Bombay begin to grip (Dubai is too recent a phenomenon and fits awkwardly into the narrative structure). Brook describes how imposed modernity, combined with epic inequality, eventually triggered three-way struggles between the colonial or autocratic state, an aggressive and modernizing local bourgeoisie, and radical labour movements anchored in the new factories. Such conflicts, albeit occurring at great human cost, generated the extraordinary, if brief-lived energies of avant-garde Leningrad, Jazz Age Shanghai and Art Deco Bombay.

Will history repeat itself in a similar pattern in Dubai, Abu Dhabi, New Songdo or others of today's instant cities? I think that such a question is equivalent to asking what time the revolution will begin in Las Vegas, the utopia of tack. Brook tends to confuse cosmopolitan modernity with malls, skyscrapers and theme parks, especially with the strange claim that "Dubai represents the world as it is". Rather than searching to "catch the glimpses of utopia within the dystopia", as he recommends, I think it would be more fruitful, as Geddes advised, to focus on the solidarities and practices of daily life.

Mike Davis is a writer and urban historian based in San Diego, California. e-mail:michael.davis@ucr.edu

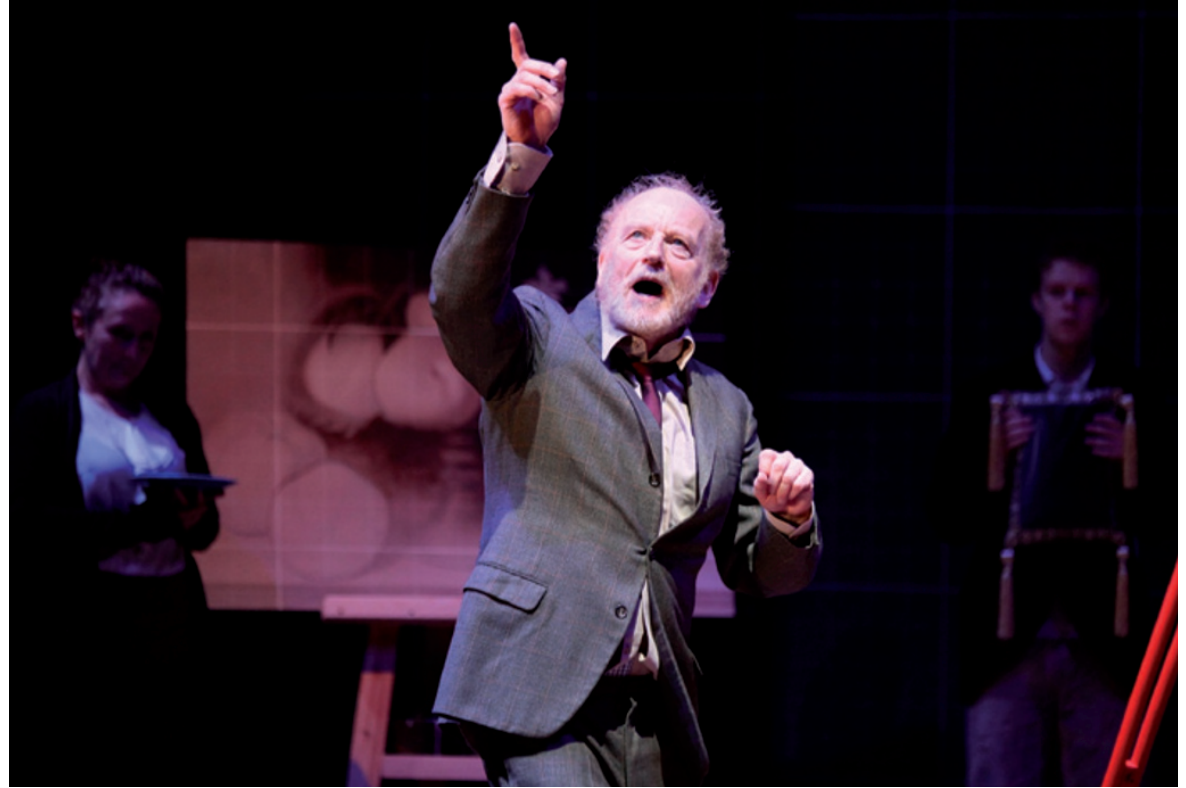

Ian McDiarmid plays the title role in Mark Ravenhill's new translation.

ARTS

\section{Reinventing Galileo}

\section{Philip Ball weighs up an exuberant Royal Shakespeare Company production of Bertolt Brecht's Life of Galileo.}

$\int t$ is one of the central works of drama about science, and one of the most controversial. Bertolt Brecht's Life of Galileo has been criticized for misrepresenting history, science and Galileo Galilei himself, with some validity. The real question, however, is whether the play works, theatrically and psychologically.

Shakespeare, after all, took vast liberties with history, yet such is his way with human portraiture that no one complains. Shakespeare and Galileo were born within a few weeks of each other in 1564 - a coincidence that the Royal Shakespeare Company (RSC) understandably makes much of for its latest production of Brecht's play. More significantly, the play shows Brecht at his most Shakespearean, with Galileo the wily, tragically compromised sensualist redeemed by self-insight that others lack - he is, as Adam Gopnik suggested in a recent article in The New Yorker, a kind of intellectual Falstaff.

The exuberance and wit of this production owe much to the new translation by RSC writer-in-residence Mark Ravenhill. Ravenhill has commented on the "comic sensibility in Brecht's language which I think [is] often overlooked", but which he and director Roxana Sibert have found in abundance. In the title role, Ian McDiarmid is sly and worldly yet succeeds in pulling off the crucial feat of making Galileo loveable. It is with the basic fabric of the play, not its realization, that the questions lie.

In retrospect, we can see that Brecht set himself an impossible task, because even now there is no consensus on Galileo. Many scientists still prefer the narrative that prevailed when Brecht first wrote the play in 1937-39, of a martyr

\section{A Life of Galileo} DIRECTED BY ROXANA SILBERT

Swan Theatre

Stratford-upon-Avon UK.

Until 30 March 2013

persecuted by the Catholic Church for his pursuit of truth about the arrangement of the cosmos. A more measured view now holds, recognizing that a less pugnacious man might have navigated the currents of the papal court more skilfully. It is certainly not to excuse the bullying, dogmatic church to point out that Galileo's evidence for a heliocentric Universe was equivocal and in some respects (his interpretation of the tides) wrong.

Galileo's mathematical approach, rightly adored by physicists today, was not, as some older science historians had it, the right way to do science. It was the right approach for celestial and terrestrial mechanics, but useless for chemistry, botany, zoology and much else. And although Einstein claimed that Galileo's rejection of logical deduction devoid of empirical input was essential to modern science, that rejection did not begin with Galileo.

Brecht must take some blame for making Galileo seem more original than he was. He fell for the idea of a scientific revolution in which great men begin thinking in a totally new way. Complaints about historical accuracy could seem carping when appraising a work of art, but Brecht himself attested of the first version of the play that "I was trying here to follow history". Brecht was in any case 